\title{
Study the Impact of use of ICT on Organization Performance in Omani SMEs
}

\author{
Khulood Said AL-Amri \\ Arti Sharma
}

\author{
Middle East College \\ Middle East College
}

\begin{abstract}
Traditionally SMEs have resource constraints in the form of information, finance and reach in the market, ICT is vital to promote strategy, performance, and growth. Moreover, Oman boasts of very high mobile phone penetration and highly connected youth, the impact of ICT in the performance of SMEs becomes all the more pronounced. This paper focuses to study the impact of the use of ICT on the organization performance in small and medium enterprises in Oman. In a knowledge-based economy, SMEs face both opportunities and challenges due to the development of ICTs. Within the country, SMEs are of huge economic and social importance and play an important role in mobilizing domestic financial resources and competencies, as well as increasing savings and channeling them into investment areas. Here comes the role of technology, where the development and innovation in ICT increase the productivity of the individual and benefit from the knowledge, science, and technology. The significance of the findings of this study is valuable to all the stakeholders - owners/managers, sponsors, entrepreneurs, financial institutions and government. The outcome of the study point towards the direction needed to make informed decisions and formulate policies about ICT investments in the country.
\end{abstract}

\section{Introduction}

History testifies that mankind has undergone several revolutions, the latest of which is information and communication technology. The present era is known as the age of scientific, information and technological wealth. This age is represented by the organic cohesion between computers and the human mind. These computers have invaded all areas of human activity such as economy, services, and communications. It has become the secretion of many technological means that have made the world a small village. Technology has enabled many economies to benefit from efficiency, speed, efficiency, improved quality as well as a competitive advantage. Organizations today adopt technology as one of the most important pillars that allow an organization to develop a strategy to ensure its success and achieve the goals that have been harnessed. Accessing and utilizing information well means timely and best decision making.

Oman believes in the importance of ICT as well as small and medium enterprises. This technology has become an element that enables any country or company to grow and compete with others effectively and efficiently. Either the number of registered with the General Authority for the Development of SMEs (RIYADA) is close to 32 thousand by the end of 2017. SMEs represent more than $90 \%$ of the number of companies engaged in economic activity (Riyada 2015).

SMEs are a vital part of the country's economy and play a crucial role in the process of economic development. It has economic and social significance that contributes to GDP and creates new jobs (labor-intensive sectors). Oman seeks to improve Omanis' lives and raise their welfare. Its economic policy depends on comprehensive and sustainable development. Oman has embarked on opening up a variety of ways for the economy in all fields through diversification of economy strategies and nondependence on oil and gas as the main source of income for the country. The concept of small and medium enterprises reflects the concept of size between them. They are expressed by the standards for the number of workers, the capital invested, the volume of production or value of production, as well as other standards. There is no single definition of what SMEs are, but will 


\section{Journal of Student Research}

Fourth Middle East College Student Research Conference, Muscat, Sultanate of Oman

stand on the definition according to the Ministry of Commerce and Industry in Oman; they have decided that small enterprises are associated with 5-9 employees with annual sales of 25,000 OMR or 250,000 OMR (Riyada 2015).

Information and communication technology (ICT) is the term product of the intermarriage of information, communication, and electronics. It is considered the most important means of transferring developing communities to more developed societies using new methods and techniques for the digital economy based on information technologies. It expresses all communication technologies in addition to wireless networks, the Internet, computers, mobile phones, social networks, video conferencing and other services that enable the user to access, store, retrieve, process, and transmit information in digital form (Aims 2019).

Small and medium enterprises have become dependent on the rapid change in information, starting with information on the size of production, investment activities, and taking into account the needs of workers. Thus, the problem identified for this research is how SMEs can be developed to meet the challenges posed by globalization in the face of the infrastructure and facilities available in Oman.

These results may help inform the roles of the workforce when technology enters their jobs and derives its benefits. It may be used by government agencies, stakeholders and sponsoring institutions to develop policies and make them applicable. This study may benefit entrepreneurs that can use the results to make decisions about investing in ICT.

\section{Experimental Procedures}

This research examined two major sources of data acquisition. Secondary sources are in books, research, and articles related to the use of ICT in small and medium enterprises. Primary sources use a specific electronic questionnaire for random thirty people as a means of measuring hypotheses. The results will be used to determine the relationship between the use of ICTs and SMEs. The objective of this methodology is to obtain a quantitative assessment of the performance of SMEs when combined with technology.

The questionnaire consisted of two parts: the first one was represented in 3 questions to obtain the demographic information required of the respondent: gender, education level, and work experience. Information about education and experience of respondents measure their culture about the use of this technology. The other part is based on three standard terms: technology pros, constraints on the introduction of technology, and the use of ICT by SMEs.

\section{Result}

\section{Section 1: demographic information}

\begin{tabular}{|l|l|l|}
\hline Value Label & Frequency & Percent \\
\hline Male & 19 & 63.33 \\
\hline Female & 11 & 36.67 \\
\hline Total & 30 & 100.0 \\
\hline
\end{tabular}

Table 1. Gender Response

\begin{tabular}{|l|l|l|}
\hline Value Label & Frequency & Percent \\
\hline High School & 11 & 36.67 \\
\hline Diploma & 8 & 26.67 \\
\hline Bachelor & 8 & 26.67 \\
\hline other & 3 & 10.00 \\
\hline Total & 30 & 100.0 \\
\hline
\end{tabular}




\section{Journal of Student Research}

Fourth Middle East College Student Research Conference, Muscat, Sultanate of Oman

Table 2. Respondent's Education

\begin{tabular}{|l|l|l|}
\hline Value Label & Frequency & Percent \\
\hline $1-3$ & 12 & 40.0 \\
\hline $4-7$ & 14 & 46.67 \\
\hline $8-11$ & 4 & 13.33 \\
\hline Total & 30 & 100.0 \\
\hline
\end{tabular}

Table 3. Respondent Experience

\section{Section 2: Likert Scale Technology pros:}

Q1: Technical means to save time and effort in work and help in the preparation of financial reports and periodic accurately.

\begin{tabular}{|l|l|l|}
\hline Value Label & Frequency & Percent \\
\hline Disagree & 5 & 16.67 \\
\hline Neither & 3 & 10.00 \\
\hline Agree & 3 & 10.00 \\
\hline Strongly Agree & 19 & 63.33 \\
\hline Total & 30 & 100.0 \\
\hline
\end{tabular}

Table 4.

Q2: The use of computer and other techniques helps support the coordination work in the organization. It also provides the possibility to exchange information in branches of the organization faster and easier.

\begin{tabular}{|l|l|l|}
\hline Value Label & Frequency & Percent \\
\hline Disagree & 3 & 10.00 \\
\hline Neither & 3 & 10.00 \\
\hline Agree & 15 & 50.00 \\
\hline Strongly Agree & 9 & 30.0 \\
\hline Total & 30 & 100.0 \\
\hline
\end{tabular}

Table 5.

Constraints facing the application of technology

Q3: Poor training and lack of experience in the use of modern technology impede its use towards the performance required for work.

\begin{tabular}{|l|l|l|}
\hline Value Label & Frequency & Percent \\
\hline Disagree & 2 & 6.67 \\
\hline Neither & 6 & 20.0 \\
\hline Agree & 11 & 63.33 \\
\hline Strongly Agree & 6 & 20.0 \\
\hline Total & 30 & 100.0 \\
\hline
\end{tabular}

Table 6.

Q4: The inability to keep up with the rapid development of modern technology reduces the level of organization performance.

\begin{tabular}{|l|l|l}
\hline Value Label & Frequency & Percent \\
\hline
\end{tabular}


Journal of Student Research

Fourth Middle East College Student Research Conference, Muscat, Sultanate of Oman

\begin{tabular}{|l|l|l|}
\hline Disagree & 3 & 10.00 \\
\hline Neither & 5 & 16.67 \\
\hline Agree & 10 & 33.33 \\
\hline Strongly Agree & 12 & 40.00 \\
\hline Total & 30 & 100.0 \\
\hline
\end{tabular}

Table 7.

The use of SMEs for ICT

Q5: The introduction of new ICT in SMEs impacts positively on the organization performance.

\begin{tabular}{|l|l|l|}
\hline Value Label & Frequency & Percent \\
\hline Disagree & 2 & 6.67 \\
\hline Neither & 4 & 13.33 \\
\hline Agree & 8 & 26.67 \\
\hline Strongly Agree & 16 & 53.33 \\
\hline Total & 30 & 100.0 \\
\hline
\end{tabular}

Table 8.

Q6: The use of ICT allows FAO staff to participate in decision-making

\begin{tabular}{|l|l|l|}
\hline Value Label & Frequency & Percent \\
\hline Disagree & 5 & 16.67 \\
\hline Neither & 8 & 26.67 \\
\hline Agree & 10 & 33.33 \\
\hline Strongly Agree & 7 & 23.33 \\
\hline Total & 30 & 100.0 \\
\hline
\end{tabular}

Table 9.

\section{Discussion}

Most of the results indicated agree to strongly agree on all the above questions. This means that many human minds are currently programmed and adapted to technological development. The use of ICT in any organization gives a positive impression. With the importance of small and medium enterprises, the use of this technology will improve the performance of the organization. Providing proper infrastructure helps the country to progress and make it free of barriers.

\section{Acknowledgements}

The success of this research belongs to Mr. Arti Sharma for her help and moral thrust. The thanks have also prevented Middle East College to allows its students the opportunity from preparing and publishing research.

\section{References}

Amis (2019) Information and Communication Technologies (ICT) [online] available from < http://aims.fao.org/es/information-and-communication-technologies-ict> [20 Nov 19]

Riyada (2013) Public Authority for Small \&Medium 


\section{Journal of Student Research}

Fourth Middle East College Student Research Conference, Muscat, Sultanate of Oman

Enterprises Development [online] available from https://riyada.om/enus/downloads/Third\%20directory\%20-\%20EN.pdf\#search=GDP [118 Nov 2019]

Riyada (2015) Riyada Mandates [online] available from < https://riyada.om/enus/aboutus/Pages/Objectives.aspx > [22 Nov 2019] 